\title{
Association of Unhealthy Food Practices with Nutritional Status of Adolescents
}

\author{
Saniya Rasheed, Maria Aslam, Marium Ejaz, Akleema Fakhar, Ayesha Asif, Hirman Amir and \\ Sidra Khalid* \\ University Institute of Diet and Nutritional Sciences, Faculty of Allied Health Sciences, University of Lahore, Pakistan \\ *Corresponding author: Sidra Khalid, University Institute of Diet and Nutritional Sciences, Faculty of Allied Health \\ Sciences, University of Lahore, Pakistan
}

\section{ARTICLE INFO}

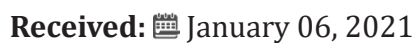

Published: 慧 January 25, 2021

Citation: Saniya Rasheed, Maria Aslam, Marium Ejaz, Akleema Fakhar, Ayesha Asif, Hirman Amir, Sidra Khalid. Association of Unhealthy Food Practices with Nutritional Status of Adolescents. Biomed J Sci \& Tech Res 33(2)-2021. BJSTR. MS.ID.005389.

\begin{abstract}
Unhealthy eating practices leading towards increase intake of junk or fast foods, intake of carbonated beverages, low hygienic practices, skipping of breakfast and low intake of fruits and vegetables among adolescents of this era. Junk food include those foods having zero nutritional values and contain more fat, sugar, artificial flavors, salts, and several additives and mostly taken by adolescents and leading towards risk of chronic diseases i.e., obesity and most probably cause micronutrient deficiencies. This study aimed to determine different causes and factors unhealthy eating practices and behaviors and how they can affect nutritional status among adolescents which recent studies show the increase consumption of fast foods, carbonated and energy drinks lead to cancers, cardiovascular disorders, diabetes, lack of concentration and several GI tract illness.
\end{abstract}

\section{Introduction}

Junk food has a low consumption of vegetables, milk, other dairy products and fruits as well as a more consumption of fats, sodium and calories from fatty foods or products having more sugars or alcoholic drinks [1]. Unhealthy diets among young people included skipping meals, eating out, eating snacks and eating fast food [2]. Unhealthy eating practices, such as breakfast skipping and higher consumption of foods high in carbs or fats, these are possible factors that cause nutrition related issues among people. The probability of chronic illnesses, such as weight gain, heart disease, bone related issues or cancer, may alleviate by an outcome of unhealthy diet [3]. The intake of fat, trans and saturated fatty acids, sodium, fiber and high cholesterol products among younger group is high and the intake of vitamin E, vitamin B6 and folic acid is low because the intake of fruits and vegetables of adolescents is low and lead to deficiency of pyrodoxine, VIT C, zinc, riboflavin, phosphorus and niacin. Insufficient energy, proteins and minerals such as iron and calcium intake cause problems related to osteoporosis and anemia $[3,4]$. Obesity and overweight keep on increasing rapidly across the world, impacting all ages and genders. Fast food intake one of the factors that have been reported to cause overweight among people [5].
In particular, fast food consumption linked to low dietary quality and detrimental nutritional habits linked to obesity, including elevated consumption of dietary fat and sugary beverages [6]. Junk food negatively affects the quality of diet, body weight and overall health. Fast foods high in sodium and low in fiber, which increases the risk of being overweight and obese [7]. Competitive products such as soda, candy, chips, sugary drinks consumption causes childhood obesity [8]. Competitive foods that affect children's diet or increase the risk of obesity [9]. Consuming processed foods rich in starch, refined grains, fats and sugar can increase weight gain. Low energy drinks were closely associated with weight gain [10]. The frequency of obesity among children and young adults have risen globally and attained epidemic proportions. The main source of refined sugar in the consumption of children and teens is sugary and carbonated drinks that have been leading towards obesity and overweight [11]. Young adults in the urban areas have generally poor eating patterns. Increase intake of carbonated and sugary beverages and increase in sedentary lifestyle and lower intake of fruits and vegetables probably leading towards increase in BMI [12].

Carbonated drinks and beverages like Pepsi, Fanta, sprite and coke are major sources of refined sugars. According to World 
Health Organization, recommendation of sugar should be less than $10 \%$ of total energy intake, to avoid risk chronic diseases among children [13]. Factors that affect childhood obesity involve food, socio economic status and physical activity. Among children, intake of carbonated and sugary drinks are elevating [14]. Adolescence is period in which young children will affect nutrition, impacting on current and potential healthcare outcomes, but adolescent diets are poorly defined worldwide. School teenagers should be encouraged to eat more vegetables and fruits and reduce carbonated drinks intake [15] (Figure 1). The implications of obesity in adolescents are complex: there is an intergenerational change of the incidence of obesity, with obesity affecting various periods of the life cycle during puberty, including under-nutrition to over-nutrition in fetal development, infancy and adulthood, and integrating poor diets and insufficient physical activity Excessive consumption of soft drinks as a well-established factor in childhood obesity triggered by soft drink consumption and the impact (excess weight gain) approach, recognizing the variety of factors that lead to soft drink consumption and how they may interact to promote these behavior, such as water access and health, and/or who produces and/or who produces them.

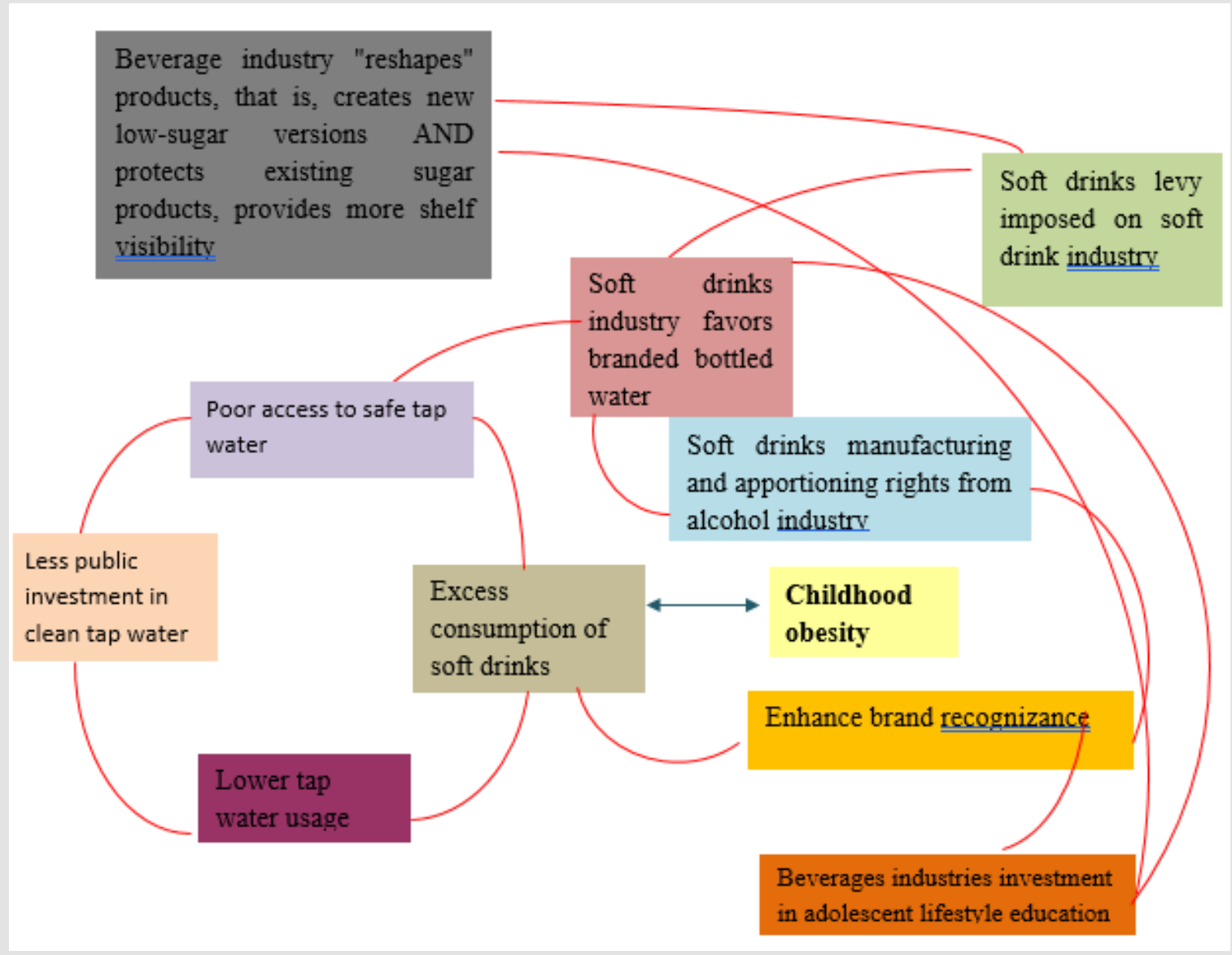

Figure 1: Mechanism of Action of Carbonated Drinks Among Obesity in Adolescents.

The promotion of soft drinks on the soft drink industry and youth obesity will change in a variety of ways, including by reformulating the products. However, research suggests that this is often not a matter of replacement (actually eliminating high sugar beverages), but instead of producing a low-sugar substitute, adding to the overall deal. This change makes the system more resilient to outside shocks [16]. Increase fracture risk and loss of bone density is associated with high consumption of carbonated drinks in adolescence [17]. High consumption of carbonated drinks leads to increased dietary phosphorus which can have detrimental effects on bone and mineral density [18]. Most of the bone mineral mass is accumulated during the first two decades of life. About $90-95 \%$ of bone mineral mass is developed in a human body at the end of adolescence [19]. As children grow up their intake of sweetened and carbonated beverages increased while milk consumption decreased. This raises nutritional concerns as high consumption of beverages leads to low bone mineral density, poor bone health, short stature and increase risk of osteoporosis and bone fractures [20]. Conversely, carbonated soft drinks intake lead towards reduce diet quality, and reduce uptake of vitamins and minerals including calcium, magnesium, potassium, protein, and vitamin C [21] (Figure 2). 


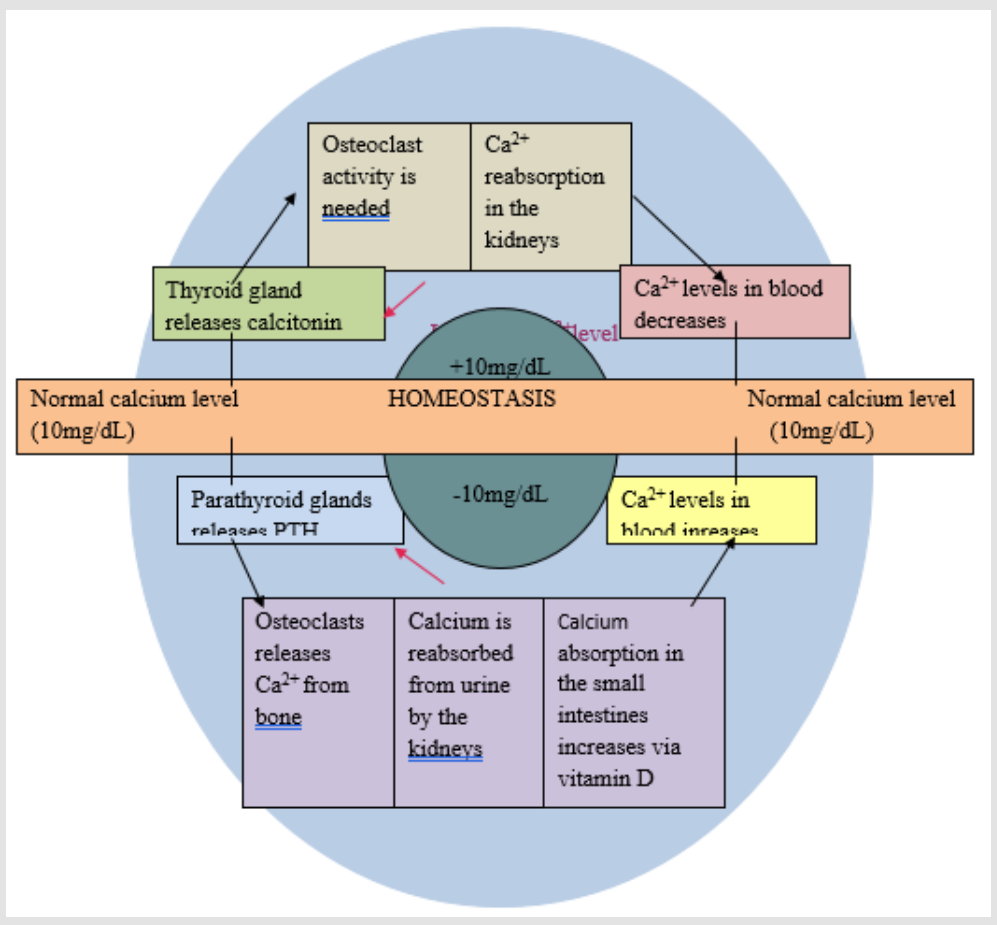

Figure 2.

More intake of beverages causes porous bones which are at high risk of fractures and other bone related problems [22]. Energy drinks are non-alcoholic beverages [23], that include fruit drinks, soft drinks, high caloric sweetener drinks like sucrose, fructose [24] which are leading source of added sugar in diet of adolescence [25]. Consumption of energy drinks has become increase in adolescence because of wide advertising of energy drinks and their easy accessibility in markets [26]. Energy drinks has no therapeutic benefit addition of pharmacology agents can increase adverse effects on health [27]. Increase consumption of soft drinks can decline the intake of milk and increase glycemic index because of increased consumption of high energy drinks [28]. Adolescents who have high intake of soft drinks has many side effects like dizziness, inability to focus, nervousness, insomnia and gastrointestinal upset [25]. Specially those who have already liver, renal and cardiovascular disease, diabetes and hyperthyroidism have severe side effect for the consumption of energy drinks [26].

The prevalence of energy drink consumption of the students is high [29].Carbonated softdrinks (and somenon-carbonated) contain a large number of harmful substances [30]. Excess consumption of energy drinks by teenagers and young adults is increasing rapidly and leading to negative impact on health and general well-being. Carbonated soft drinks have more toxic effects on health. Caffeine in carbonated beverages can cause some types of cancer, insomnia, irregular heartbeats, high blood pressure, high cholesterol, breast lumps and some nutrient depletion. Carbonated soft drinks cause malnutrition because they can cause gastrointestinal diseases that can cause dwarf growth and other physiological problems. Soda cans contain bisphenol (hormonal destructor) and adversely affect the proper development of adolescent [31]. Energy drinks are the part of a diet in which nutritional requirement is in between the ages from years $13-18$ in which it can be a hormonal change in the result of growth and development [32].

\section{Effects of Energy Drinks on Adolescent}

A diet rich in sugar has been shown to be linked with good fitness, weight gain mainly due EDs are rich in sugar and are prone to induce weight gain due to unnecessary calorie intake; their ingestion does not result in satiety unlike similarly Solidcalorie diets. Being fat or overweight is, in Turn, proven disease risk including diabetes, Cardiovascular disorders and fatty liver disease In fact, high levels of sugar are linked with diabetes, and are believed to lead to mental health issues such as depression, fatigue, anxiety and sleep disorder; sleep loss may also raise the risk of fatigue. Caffeine intake is associated with elevated rates of a recognized risk factor for tachycardia, blood pressure, and Cardiovascular Illness While caffeine is generally a stimulant, it is known how this effect manifests Is seen to differ in dose: $250 \mathrm{mg}$ of caffeine intake It was found to cause elation, intake $500 \mathrm{mg}$ Known to induce irritability Caffeine has been linked with a range of mental health concerns including fatigue, depression, and anxiety, along with a host of health habits including abuse and violence, but causality cannot be determined. The bulk of the data available is for cross-sectional research and that makes it hard to think about the possible pathways that connect intake to mental health outcomes. 
For example, mental health consequences such as depression and anxiety may lead to a consumption of caffeine to cultivate feelings of health and energy Caffeine intake is also linked with sleep disorders. Although exhaustion can in effect cause headaches, Stomach issues, mental health problems, behavioral disorders and Weak concentration, it can also promote increased intake of caffeine to support a sense of well-being. It is likely that the connection between intake of caffeine and mental health and sleep disorders is bidi reactional [33] (Figure 3). Rodrigues PR, et al. [1] carried out a study on the poor eating patterns of adolescents in middle-western Brazilian secondary schools correlated with meal skipping to establish the association between eating habits and diet consistency in Brazilian adolescents aged 14 to 19 years $(\mathrm{N}=$ 1139). Diet was distinguished by an poor diet: low intake of fruits, vegetables and dairy / milk products, and heavy fat and sodium use. While 14 percent of adolescents had an unsatisfactory meal profile, 47 percent, 78 percent, and 52 percent of adolescents reported daily breakfast, lunch, and dinner intake. Just 28 per cent of adolescents reported a satisfactory meal profile. Skipping meals is associated with a low quality diet, particularly in relation to low fruit and vegetable consumption and high sodium and calories from fats, added sugars and alcoholic beverages [1].

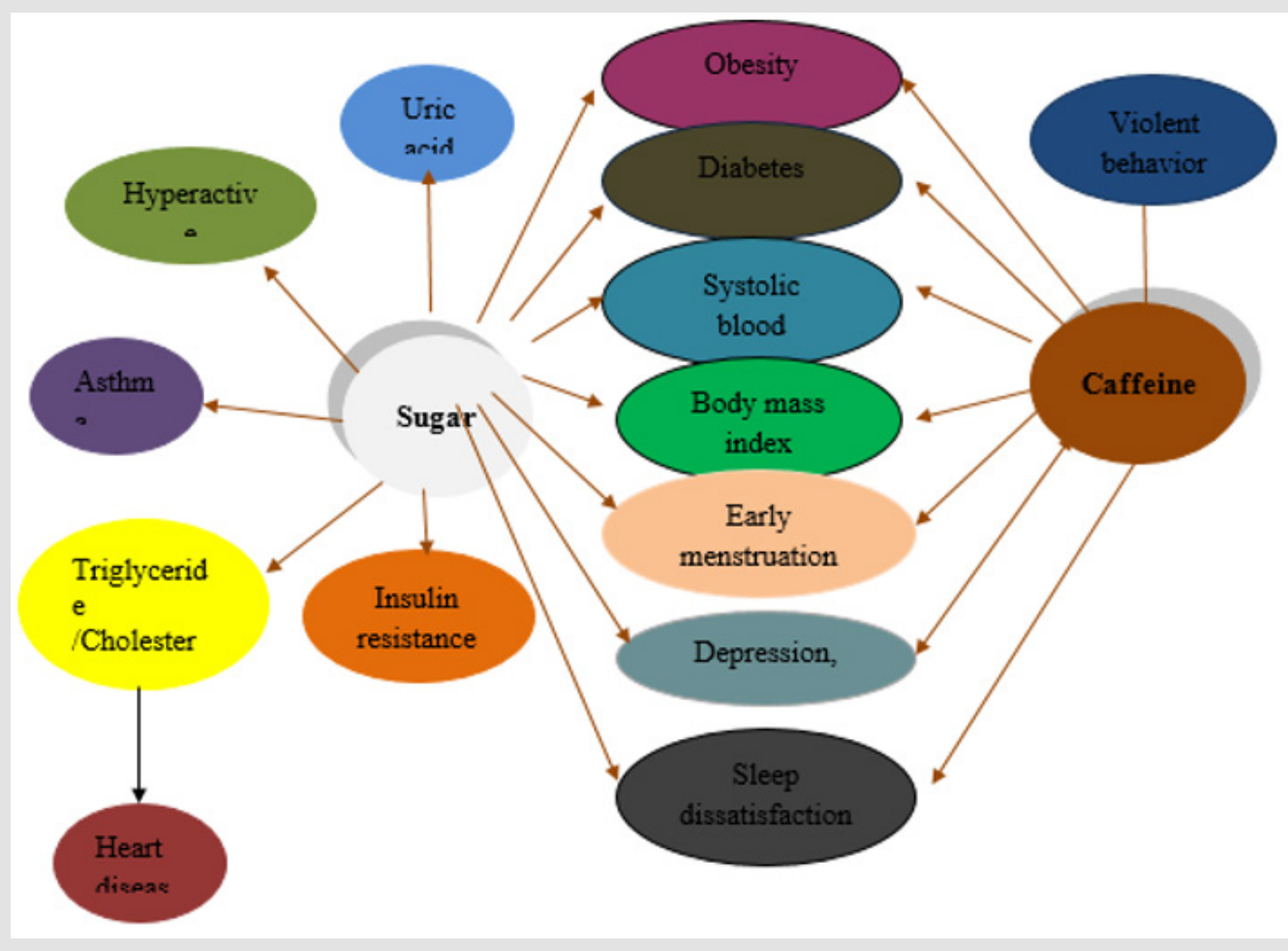

Figure 3.

Neslișah R, et al. [3], conducted a cross-sectional analysis on energy and nutrient consumption and diet habits among Turkish university students, in which 400 students (167 females, 233 males) aged 19-24 participated. The most missed meals were breakfast and lunch ; $47.7 \%$ of students who missed breakfast and $25.2 \%$ of those who missed lunch. The energy deficiency rates were $78.4 \%$ for men and $81.1 \%$ for women [3]. Shah T, et al. [5] conducted a comprehensive cross-sectional analysis to examine obesity, overweight and its correlation with fast food consumption in medical students, focusing on the relationship between body mass index and fast food intake, correlated soda consumption and physical activity among 138 students.(more than 90\%) of which 147 students were eating fast food. 47Among these, 34.05 per cent were pre-obese and obese. Of the 147 pupils, 87 (59.18\%) were within regular weight limits, and 13 (8.88\%) were heavy. Throughout our study, 90 per cent of students ate fast food throughout their diet but 22.45 per cent and 9.52 per cent respectively were pre-obese and obese. Similarly, the elevated body mass index was strongly related to a higher intake of fast food and less exercise each week. In addition, the association between BMI and fast food consumption has been important with reduced physical activity and soft drink intake [5].

Anderson B, et al. [6] performed a survey to investigate Michigan adults with fast food intake and obesity to reduce chronic disease. The primary aim of this research was to examine the incidence and characteristics of fast food intake and obesity prevalence in Michigan adults. Evidence from 12 questions relating to fast food intake found in the 2005 Michigan Behavioral Risk Factor Survey is analysed. The rate was 28 per cent of daily fast-food intake. The frequency was higher in $37 \%$ of people between 18 and 24 years of 
age than in women in $37 \%$ of men between 55 and 64 years of age and in men (23\% vs. 33\%) [6]. Al Otaibi HH, et al. [7] conducted fast food intake correlated with obese/ overweight risk among female university students in Saudi Arabia. The research aimed at exploring the pattern of fast food eating among university students and assessing the association between fast food intake and body weight status. Overweight / obesity prevalence was 29.7 percent. A total of 130 (47.1 per cent) students reported eating fast food two or more days a week, and lack of cooking skills were the key reasons for intake. For fast food stores, 80 percent of students did not read dietary facts and only 5 percent of students still order nutritious items or much of the time.

Two-thirds of students eat fast at home, which may be due to the ease of ordering and serving at home or going to a restaurant compared to university. The link between fast food intake and onset of obesity had been reported [7]. Beal T, et al. [15] performed a Meta-Analysis of World School-based Student Wellbeing Surveys to observe diets of adolescents globally and to investigate dietary patterns among them. It was a cross sectional study, method of random effect meta-analysis for intake of fruits, vegetables and carbonated beverages had been estimated among 12 to 17 years old children. Results shown, in total, 34.5 percent of fruits consumed less than once a day, 20.6 percent of vegetables consumed less than once a day, 42.8 percent adolescents had intake of carbonated drinks on daily basis, and 46.1 percent consumed fast food on weekly basis. Conclusion of this study was that school going adolescents had inadequate intake of vegetables and fruit and adequately consume carbonated sugary drinks, but subpopulation varies widely [13]. Yang L, et al. [13] compared carbonated soft drinks consumption by young teenagers in fifty-three low- and middle-income countries. Method of Global School-based Student Health Survey data from 2009 to 2013 were used to estimate 137449 young adolescents aged 12 to 15 years on mean level of intake of carbonated sugar drinks.

The results were that young adolescents recorded 1.39 time a day consume carbonated soft drinks. 54.3 per cent of adolescents reported drinking a carbonated soft drink at least once a day. Result of the study showed that in middle-income and low-income countries, carbonated soft drink intake among young teenagers was greater. It was necessary to take steps to reduce the teenage consumption of carbonated soft drinks in that countries [15]. Katzmarzyk P, et al. [34] performed a cross-sectional analysis to investigate in a global survey the association between soft drink consumption and obesity in children aged 9-11 and to examine the relationship between average soft drink intake (containing sugar) and diet (artificially sweetened) cold drinks and obesity in children from 12 countries. Method used to check the intake was through food frequency questionnaire, BMI scores and percentages of body fat. 6162 children between the age 9-11years were included in the sample. The results shown that there was a high possibility of obesity among girls (OR $=1.46$ (95 percent CI: $1.00-2.13)$ ) among those who recorded regular soft drinks and there was a high probability of obesity in boys (1.57 (1.14-2.17)) among those who recorded drinking soft drinks once a week.

The conclusion of this large multinational children study found a weak positive relationship between regular soft drinks intake and childhood obesity [34]. A cross-sectional study was conducted by Aziz F, et al. [35] in order to obtain the incidence of obesity among young female university students aged 19-23 in conjunction with the Body Mass Index (BMI) in accordance with the WHO categorization. Sample of 180 girls have been collected and method used to analyze the data by $\mathrm{T}$ test presented as \pm SD. The results shown that $17.77 \%$ (33) of girls were underweight, $19.53 \%$ (106) were normal and $29.59 \%$ (30) were overweight and $30.46 \%$ (11) were obese. In general, high intakes of fast food, soft drinks, carbonated sugary drinks like coca cola, tea were found in adolescent diets. All these disordered eating habits among young girls were more likely to achieve overweight and obesity. Health awareness program against carbonated sugary drinks and junk food should be addressed to achieve maximum health goals [35]. The association between sweetened or carbonated sugar beverages and adolescent bone mineral density was studied by Rafoss $M$, et al. [17]. It was conducted to learn whether low or high carbonated soda intake is correlated with reduced bone mineral density in adolescents. The study included 900 teenagers from Tromsø, et al. Municipality.

In relation to drinking carbonated beverages, the boys had a higher consumption pattern $22.3 \%$ of the girls said they never drank carbonated beverages, but only $6.1 \%$ of the boys answered the same. A small ratio of girls $8.9 \%$ said they drank 2 or more glasses daily, while $23.7 \%$ of the boys said the same [17]. Another study was conducted by Al Raddadi R, et al. [19] to assess the prevalence of lifestyle behaviors that may impact bone health in relation to the status of vitamin D among Saudi women teenagers and to classify the prevalence of bone health and the factors associated with vitamin D deficiency among Saudi women students. A crosssectional longitudinal analysis of 421 randomly chosen female teenagers was performed at high schools in Jeddah City. About 67.5 percent of students were deficient of vitamin $D$ although 21 percent had inadequate vitamin D levels, which indicated that students were at risk of developing osteoporosis related to many risk factors like carbonated soda consumption [19].

The research conducted by Golloso Gubat MJ, et al. [20] on Filipino Children and Adolescents Beverage Intake ( $7^{\text {th }}$ National Diet Survey): Food issues and future policy consequences affecting a total of 17 regions and 79 provinces utilizing the 2003 master's sample of the Philippine statistical authority, formerly the national statistics office (NSO). Participants for this study were categorized into 3 age groups: pre-school children (6 months to 5 years old), school-aged Children (ages 6 to 12) and adolescents (ages 13 to 19 ) the study was performed to cover the beverage consumption 
data of the Filipino school going children beverage consumption. High milk intake was found in preschool children as compared to low milk intake and high beverage intake in school going children and adolescents. $14 \%$ of Preschool children drank soft drinks while $17 \%$ was school going children and $25 \%$ were adolescents. Findings indicated that cola was the most popular beverage among children [20]. To measure the consumption and nutritional content of carbonated beverages in male adolescents from the 2007 2009 KNHANES (Korean National Health and Nutrition Review Survey) combined Bae YJ, et al. [21] carried out a study.

Subjects were split into two groups: LCDI (low intake of carbonated beverages ( $<1$ time / week), $\mathrm{n}=362$ ) and HCDI (high intake of carbonated beverages (about 1 time / week), In the high carbonated drink intake group the consumption of plant protein, magnesium, vitamin C phosphate, and potassium was slightly lower relative to the low carbonate intake group. The calculated sufficient protein and vitamin $\mathrm{c}$ and phosphorus demand in the high carbonated drink intake category was also smaller than in the low carbonated drink intake group. The estimated adequate requirement of protein and vitamin $\mathrm{c}$ and phosphorus was also lower in high carbonated drink intake group as compared to low carbonated drink intake group [26]. Musaiger AO, et al. [26], determined the awareness, attitudes, and consumption of energy drinks among teenagers in Saudi Arabia aged 1061 school children (12-19yrs). Questionnaire was issued on collecting student data. As a result, males consume energy drinks at 71.3 percent and females consume energy drinks at 35 percent. The main reason why energy drinks are drunk is 58 percent taste and flavor and $43 \%$ gender difference among energy intakes. Total $45 \%$ adolescents drank energy half of them have not specific knowledge about the ingredients use in energy drinks. $67 \%$ considered energy drink to be a soft drink [36].

Oh JW, et al. [36] conducted related energy intake factors for certain middle school students in Incheon area research in 2017 to examine the consumption of energy drinks and caffeine tolerance among middle school students of 313 middle school students in Inchon area from which 133 male students and 180 female students. Questionnaire was given among them. As a result of recognition of energy drinks monster energy $13.8 \%$, red bull $24.3 \%$, wolf energy $13.8 \%$ their study showed that there was more difference in Energy consumption, consumption purpose, intake time and location but the energy drink duration did not vary. As a consequence of the interpretation of challenging caffeine was also found of green tea, male students gave tea, cola according to gender 2.25 points and female students gave 2.61 points. As a result, there is more difference in male and female perception for the consumption of energy drinks [37]. Correlation among teenagers in China between soft drink and sweet food intake and suicidal behaviour was determined by Pan X, et al. [37]. Sample size from 100 schools aged 12 to 19 years was chosen in 2005 in Jiangsu Province China. In current research they observed that soft drink intake in students was 20.5 percent and suicidal ideation was 18.6 percent.

The suicide attempt incidence figure was 6.2 percent for people who do not consume soft beverages and 12.8 percent for those who drink at least three times a day. The risk of suicidal attempts from the consumption of energy drinks increased by 80 percent, and we found that there was a positive association between them from soft drink to suicidal behavior [38]. Trends of energy intake of beverages among adolescents was discussed by Costa BM, et al. [38]. It picked 399 Australian teens aged 12-18 years. The research was performed on the basis of three criteria testing drinking habits of the subjects, knowledge of existing recommendations for energy drink intake and physiological symptoms. As a result, they observed a $56 \%$ lifetime intake of energy drinks. $28 \%$ of the study ingested on a monthly basis and $36 \%$ of users surpass the regular recommendation's intake cap. Throughout the study, it was found that because of less education, the majority of participants assume that energy drinks is healthy for children, teenagers and adults. By intake of energy beverages [39].

A study by Ryu SH [39], investigated the energy consumption status and related factors among male and female high school students in the Deajon area study. To test energy consumption in Daejeon high school students Sample size of 664 high school students was picked at fifteen. Between them was issued questionnaire. As a result, 73 percent of students have been consuming energy drinks. Male students drink more than female students. The main explanation for the intake of energy drink was nice taste of energy drink 28 percent, remain alive 54 percent from the ingestion of energy drink and 17 percent concentration percentage. They find that school marks of both male and female students are adversely affected by energy drink intake. Yet even the students who felt adverse effect in them could not avoid energy drink intake [40]. An emerging adolescent health risk: Azagba S, et al. [30] conducted caffeinated energy consumption trends among high school student research. The purpose of the study was to analyze patterns, prevalence and relationships of energy drinks among adolescents. In 2012, 8,210 students from the 7, 9, 10 and 12 classes were obtained from schools in New found land, Canada. The value of energy drinks among high school students was too high. In the end, the effect was depression and sensation seeking people who were linked to non-users for energy drinks [30].

Jan An R [40] performed study, aiming to analyze fast foods which can be consumed in US adults on daily energy intake and nutrient intake. The sample size was 18,098 National Health adults at the age of 18, and a 2003-2010 diet study had been noted. The result was to avoid fast food due to the high number of total fats, saturated fat and cholesterol when full restaurant food was consumed from home at the time [41]. Another study was carried out among Naval Aviation candidates by Sather TE, et al. [41] on energy drink and nutritional supplement beliefs. Medicine in technology and human 
health. The energy drinks should be used to consider possible health risks. Anonymous 44 item survey collected which naval aviation candidates can fill in or complete. We got a response rate of 100 per cent among energy drinks in this. The result that the relationship between the assumptions about the health of energy drinks $\{r(02)=-0.23\}$ or the negative relationship or association between them can be reversed between the additional perception for consuming energy drinks [42]. In 2017 Jul the author Yang L, et al. [43] conducted a report on carbonated soft drinks among young adolescent's aged 12 to 15 in 53 low- and middle-income countries. The study was conducted to compare carbonated soft drink consumption among young teenagers in low- and middleincome countries.

The sample size of 137449 young adolescents between the ages of 12 and 15 was chosen from schools in different countries, two sampling processes are used. Students were given Questionnaires. As a result, 95 percent of teenagers drink carbonated beverages 1.39 times a day and 53 percent of teenagers eat carbonated drinks once a day. In comparison, Kiribati consumes 0.52 per cent of carbonated drinks and Suriname consumes 2.39 per cent. As a result, soft drink consumption is higher in middle income than low income [43].

In Aug 2012 Ratnayake N and Ekanayake L published a report on soft drink consumption. The study was carried out to determine the factors associated with the consumption of sugar sweetened soft drinks in adolescents from Sri Lanka. The Questionnaires were given to students. As a result, $82 \%$ of the students drank soft drinks once a week while $48 \%$ drank soft drinks once a week. The study showed that most students drank carbonated drinks once a week and found a link between the consumption of these drinks and several social demographic factors [44].

Gupta R, etal. [45] determined knowledge, attitude, and practices of soft drinks among teenage students and their dental health study. The goal of the study was to analyze the knowledge, attitudes and practices of soft drinks and their dental health among 18-25-yearold students. It picked a sample size of 100 MBA students. Students were given Questionnaires. As a result, 58\% of students consume carbonated beverages twice a day, $39 \%$ of students face problems after intake and $48 \%$ feel discomfort after a couple of minutes of getting drinks. In the study, they found that the prevalence rate of discomfort after consumption of carbonated beverages is high and the frequency rate in this research is low [45]. A study performed by PARALKAR $\mathrm{N}$ concluded that flavored soda was consumed daily while canned fruit juices were rarely consumed while fresh fruit juices were consumed once a day or once every three days. By the findings of the study, female drinks more packed juices than male ones [46]. Nowak D, et al. [47] analyzed the consumption of caffeinated energy drinks among Polish adolescents. The research was organized to test adolescents' consumption of energy drinks. Students got a questionnaire.
As a result, 67 per cent of students consume energy drinks. Sports drink intake is more of an energy drink than any other. They discovered in the study that energy drink is more popular among teenage boys than girls [47].

Alsunni AA and Badar A evaluated for the consumption of energy drinks in Abbottabad. The energy drinks intake leads to many illnesses. Users of energy drinks were 54.60 percent males and 26.15 percent females. By spending time with family and friends, stay healthy as Caffeine was present in energy drinks, the explanation for the consumption of energy drinks. There were $36.70 \%$ males and $14.28 \%$ females who should never have suffered consequences [48]. Born KA, et al. [49] studied benefits from chocolate milk exercise supplements. It was accomplished that how much strength they obtain from chocolate milk or supplements [49]. In 2019, Mutabazi MV launched a survey of energy drink consumption trends among college students. The study's main purpose teaches us regarding soft drink intake, frequency and prevalence. Study sample size was 496. 51 per cent of people consume more soft drinks to enjoy while 51 per cent take soft drinks to sleep or to increase their energy [50].

In 2017, a study was conducted in Nairobi, Kenya by Njoroge J on Factors That Influence Consumer Purchasing Behavior in Consumption of Coca Cola Novida Malt Soft Drinks. The purpose of purchasing soft drinks, or their purchase can be identified. The sample measurements were 377. By analyzing data, they may analyze its frequency and percentages by sample size [51]. A cross-sectional research was conducted to classify the prevalence of Silva JB, et al. [52] and the factors associated with insufficient milk intake among adolescents. A sample size of 108,828 teenagers in Brazillain was taken. Results showed that in 58.9 per cent of adolescents there was sufficient milk intake. It was concluded that there was a prevalence of insufficient milk intake among Brazilian teens [52]. In 2019, Taher AK, et al. [53] conducted another cross-sectional study to evaluate the association between consumption frequency of meals taken and meals taken and diet. The standard of teenagers in UK. They contained sample sizes of 2045 British teenagers aged 11-18 years. The tool used for assessing diet quality was the Diet Quality Index for Adolescents (DQI-A). Mean diet quality score for all adolescents was $20.4 \%$ (overall DQI-A score range is -33 - $100 \%$ ).

After adjusting for gender, age, household income, the DQI- A\% score was higher for low and medium takeaway consumers by $7.4 \%$ and $3.5 \%$ compared to frequent consumers. Conclusion showed that frequent intake of outside meals had negative effects on adolescent diet quality [53]. A cross sectional study was conducted by Krishna GR and Somavarapu S of which aim was to understand that why people preferred to eat outside and the ways they utilized the restaurants according to their needs, consumer's awareness on health issues related to consumption of restaurant foods and the roles of restaurants in society. A sample size of 100 adolescents was taken. Study was done through properly designed questionnaire 
among the population of Nellore district, Andhra Pradesh. Result showed that 62 people eat less than once a week, 13 of them eat 1-3 times per week, 14 of them eat 4-6 times per week 11 of them eat Daily from outside and the reason behind people eating outside was trying different foods of different tastes, to maintain socialating and their friend circles and to enjoy the foods that are generally considered unhealthy. To experience fresh air and dining out and avoiding the same monotonous routine can be some other reasons [54].

Another cross-sectional study was conducted by Mandoura N, et al. [55] to examine the factors contributing to junk food consumption and the prevalence of junk food in Saudi adults in Jeddah.. A sample size of men 146 and women 254 was taken. Overall, the junk food intake was highly prevalent in both genders (86.5\%) with it being $87.4 \%$ in Saudi women and $85.6 \%$ in Saudi men [55]. A cross sectional was conducted by Sanlier N, et al. [56] about the young consumers' consumption behaviors. A sample size of 847 students was selected randomly which included university and high school students. majority students were aged between 19-22 years old and were $43.4 \%$ male and female were $56.6 \%$. A questionnaire was given to every individual for assessment of consumption behavior. Results indicated that $40.1 \%$ people consumed junk food 2-3 times/week while $23.3 \%$ people eat it every day [56]. Agarwal VV, et al. [57] examined the personal, environmental, and social factors linking the difference between junk and normal food consumption in college students. A sample size of 204 adolescents was selected and the results indicated that females showed a greater tendency than their female counterparts and peer pressure was selected by $21.1 \%$ respondents as their food choice selection [57].

A cross sectional was conducted by Banik R, et al. [58] to determine the prevalence of fast-food consumption. 518 adolescent students were selected by a multi-stage sampling technique from five colleges. A questionnaire was used as a data collection tool. About $64 \%$ of the participants consumed fast foods frequently 3 times/week while 36\% consumed less frequently which in once /week [58]. Lopez Quintero C, et al. [59] accessed the behavior an intention of students in washing their hands before and after consuming food and after going to the toilet. Only 33.6\% of the sample reported washing hands regularly after and before eating

Table 1: Unhealthy Dietary Pattern and Skipping Meals. while only $7 \%$ reported access to soap and water regularly at schools. Conclusion showed that scarcity of facilities at schools thwarts the children from adopting proper hygiene practices [59]. Peltzer K, et al. [60] to investigate the oral health behaviors like teeth brushing. An anonymous questionnaire was distributed in 19,560 students of the 27 universities of 26 countries of Asia, America and Africa... Results showed that $67.2 \%$ of students brushed their teeth twice/day $28.8 \%$ about once/day and $4.0 \%$ never.

Teeth brushing in the student were found to be low due to weak beliefs in teeth brushing, less fruit consumption and excessive junk food consumption and low physical activity [60]. Pekeri, et al. [61] evaluated oral health behaviors of dental students. The study included 267 students out of which 143 were male and 153 were female. Mean age among the students was 21.16 while 141 were pre-clinical students and 126 were clinical students There was a statistical difference among hygiene practices between females and males and difference between teeth brushing and use of mouth washes between smokers and nonsmokers. The results indicated that female students were more conscious of dental hygiene and nonsmokers used mouth washes on regular basis compared to smokers [61]. Sultana M, et al. [62] 200 studied undergraduate students were selected for a cross sectional study, by using pretested questionnaire, including the checklist regarding hand washing practices. The mean age of the participants was 20.4 years.

Only $22.5 \%$ students used hand wash and soap to wash their hands while majority of students washed their hands with water only. Majority of participants scored 50.81\% in hand washing practices while 66 was considered the total score with all the perfect correct answers [62]. Sihra J, et al. [63] determined the basic personal hygiene practices of the students.1385 students were selected from selected schools of Jaipur in 2017 for a cross sectional study. Two-stage sampling in which first the schools were selected and then later the students were selected did the sampling. The study results indicated that $73.6 \%$ children practiced cutting of nails after one week while $78.8 \%$ had knowledge regarding the nail cutter. The conclusion indicated that children have good knowledge of hygiene practices, but implementation is low due to several factors like socio economic status or the non-availability of facilities [63] (Tables $1 \&$ 2).

\begin{tabular}{|c|c|c|c|c|}
\hline Title & Study design & Sample characteristics & Results & References \\
\hline $\begin{array}{c}\text { Association of Unhealthy Eating } \\
\text { Habits With Meal Skipping In } \\
\text { Adolescents [1]. }\end{array}$ & $\begin{array}{c}\text { Observational } \\
\text { study }\end{array}$ & $\begin{array}{c}\text { adolescents aged 14 to 19 } \\
\text { years (N= 1139) }\end{array}$ & $\begin{array}{c}14 \% \text { unsatisfactory meal profile,47,72 } \\
\& 52 \% \text { daily breakfast, lunch dinner } \\
\text { and 28\% satisfactory meal profile. }\end{array}$ & Rodrigues PR, et al. [1] \\
\hline $\begin{array}{c}\text { Energy and Nutrient Intake And } \\
\text { Food Patterns Among Turkish } \\
\text { University Students [3]. }\end{array}$ & $\begin{array}{c}\text { Cross sectional } \\
\text { study }\end{array}$ & $\begin{array}{c}400 \text { students (167 } \\
\text { females,233 males) aged } \\
19-24 .\end{array}$ & $\begin{array}{c}47.7 \% \text { missed breakfast \& lunch } \\
\text { while 25.2\% missed lunch. Energy } \\
\text { deficiency rates of men were 78.4\% } \\
\text { and females 81.1\%. }\end{array}$ & Neslişah R, et al. [3] \\
\hline $\begin{array}{c}\text { Assessment of Obesity, } \\
\text { Overweight And Its Association } \\
\text { With The Fast Food Consumption } \\
\text { In Medical Students [5]. }\end{array}$ & $\begin{array}{c}\text { Comprehensive } \\
\text { cross-sectional } \\
\text { study }\end{array}$ & $\begin{array}{c}\text { Total= } \\
147 \text { students } \\
\text { limits and 13 were heavy. }\end{array}$ & $\begin{array}{c}90 \% \text { ate fast food throughout while } \\
22.455 \text { \& } 9.52 \% \text { were pre obese or } \\
\text { obese. Elevated BMI related to higher } \\
\text { fast-food consumption. }\end{array}$ & Anderson B, et al. [6] \\
\hline
\end{tabular}




\begin{tabular}{|c|c|c|c|c|}
\hline $\begin{array}{l}\text { Fast-Food Consumption and } \\
\text { Obesity Among Michigan Adults. } \\
\text { Preventing Chronic Disease [6]. }\end{array}$ & $\begin{array}{l}\text { Survey based } \\
\text { study }\end{array}$ & $\begin{array}{l}12 \text { questions answered by } \\
\text { Michigan adults in } 2005 \\
\text { Michigan Behavioral Risk } \\
\text { Factor Survey }\end{array}$ & $\begin{array}{l}28 \% \text { of daily fast food intake. } \\
\text { Frequency was higher in } 37 \% \text { women } \\
\text { aged 18-24 than in men } 55-64 \text { years } \\
(23-33 \%)\end{array}$ & Anderson B, et al. [6] \\
\hline $\begin{array}{l}\text { Fast Food Consumption } \\
\text { Associated With Obesity/ } \\
\text { Overweight Risk Among } \\
\text { University Female Student In } \\
\text { Saudi Arabia [7]. }\end{array}$ & $\begin{array}{l}\text { Observational } \\
\text { study }\end{array}$ & $\begin{array}{l}\text { Female university students in } \\
\text { Saudia Arabia }\end{array}$ & $\begin{array}{c}47 \% \text { students ate fast food twice/ } \\
\text { thrice a week. } 80 \% \text { didn't read food } \\
\text { labels and only } 5 \% \text { still ordered } \\
\text { nutritious items }\end{array}$ & Al Otaibi HH, et al. [7] \\
\hline $\begin{array}{l}\text { Global Patterns Of Adolescent } \\
\text { Fruit, Vegetable, Carbonated } \\
\text { Soft Drink, And Fast-Food } \\
\text { Consumption [15]. }\end{array}$ & $\begin{array}{l}\text { Observational } \\
\text { meta analysis }\end{array}$ & 12-7 year old school children & $\begin{array}{c}34.5 \% \text { fruits and } 20.6 \% \text { vegetables } \\
\text { consumed less than once/day } \\
42.8 \% \text { consumed col drink on daily } \\
\text { basis while } 46.1 \% \text { consumed fast food } \\
\text { weekly. }\end{array}$ & Beal T, et al. [15] \\
\hline $\begin{array}{c}\text { Consumption Of Carbonated Soft } \\
\text { Drinks Among Young Adolescents } \\
\text { Aged } 12 \text { To } 15 \text { Years In } 53 \text { Low- } \\
\text { And Middle-Income Countries } \\
\text { [13]. }\end{array}$ & $\begin{array}{l}\text { Observational } \\
\text { study }\end{array}$ & $\begin{array}{c}137449 \text { young teenagers in } \\
\text { fifty-three low- and middle- } \\
\text { income countries aged } 12-15 \\
\text { years. }\end{array}$ & $\begin{array}{l}\text { young adolescents recorded } 1.39 \text { time } \\
\text { a day consume carbonated soft drinks. } \\
54.3 \text { per cent of adolescents reported } \\
\text { drinking a carbonated soft drink at } \\
\text { least once a day. The rate was higher } \\
\text { in low economic countries. }\end{array}$ & Yang L, et al. [13] \\
\hline $\begin{array}{l}\text { Relationship Between Soft Drink } \\
\text { Consumption And Obesity In 9-11 } \\
\text { Years Old Children In A Multi- } \\
\text { National Study Nutrients [34]. }\end{array}$ & $\begin{array}{l}\text { Cross sectional } \\
\text { study }\end{array}$ & $\begin{array}{l}\text { 6162 Children aged 9-11 } \\
\text { from } 12 \text { countries. }\end{array}$ & $\begin{array}{c}\text { High possibility of obesity among girls } \\
\text { (OR = } 1.46 \text { ( } 95 \text { percent CI: } 1.00-2.13 \\
\text { while obesity in boys was }(1.57 \\
(1.14-2.17) \text { ) who drank cold drinks } \\
\text { once a week. }\end{array}$ & $\begin{array}{c}\text { Katzmarzyk P, et al. } \\
{[34]}\end{array}$ \\
\hline $\begin{array}{c}\text { Prevalence Of Overweight And } \\
\text { Obesity Among Young Female } \\
\text { Students In Association With BMI } \\
\text { [35]. }\end{array}$ & $\begin{array}{l}\text { Cross sectional } \\
\text { study }\end{array}$ & 180 girls aged $19-23$ & $\begin{array}{c}\text { It was concluded that } \\
17.77 \%(33) \text { of girls were } \\
\text { underweight, } 19.53 \%(106) \text { were } \\
\text { normal and } 29.59 \%(30) \text { were } \\
\text { overweight and } 30.46 \%(11) \text { were } \\
\text { obese. }\end{array}$ & Aziz F, et al. [35] \\
\hline $\begin{array}{l}\text { The Association Between Sugar } \\
\text { Sweetened Or Carbonated } \\
\text { Beverages And Bone Mineral } \\
\text { Density In Adolescents Taking } \\
\text { Part In The Fit Futures Study [17]. }\end{array}$ & $\begin{array}{l}\text { Observational } \\
\text { study }\end{array}$ & $\begin{array}{l}900 \text { teenagers from Tromsø } \\
\text { and Balsfjord Municipality }\end{array}$ & $\begin{array}{l}22.3 \% \text { girls never drank beverages } \\
\text { while only } 6.1 \% \text { boys answered the } \\
\text { same. } 8.9 \% \text { girls drank } 2 \text { or more } \\
\text { glasses/day while } 23.7 \% \text { said same. }\end{array}$ & Rafoss M, et al. [17] \\
\hline $\begin{array}{l}\text { Prevalence Of Lifestyle Practices } \\
\text { That Might Affect Bone Health } \\
\text { In Relation To Vitamin D Status } \\
\text { Among Female Saudi Adolescents. } \\
\text { Nutrition [19]. }\end{array}$ & $\begin{array}{l}\text { Cross-sectional } \\
\text { study }\end{array}$ & $\begin{array}{l}421 \text { randomly chosen } \\
\text { females from schools in } \\
\text { Jeddah }\end{array}$ & $\begin{array}{l}\text { About } 67.5 \text { percent of students were } \\
\text { deficient of vitamin D although } 21 \\
\text { percent had inadequate vitamin } \\
\text { D levels, which indicated risk of } \\
\text { osteoporosis. }\end{array}$ & $\begin{array}{l}\text { Al Raddadi R, et al. } \\
\text { [19] }\end{array}$ \\
\hline $\begin{array}{l}\text { Beverage Consumption Of Filipino } \\
\text { Children And Adolescents (7th } \\
\text { National Nutrition Survey): } \\
\text { Nutritional Concerns And } \\
\text { Potential Policy Implications [20]. }\end{array}$ & $\begin{array}{l}\text { Survey based } \\
\text { study }\end{array}$ & $\begin{array}{c}2003 \text { master sample of } \\
\text { Philippines statistical } \\
\text { authority was used. } 3 \text { age } \\
\text { groups: pre-school children } \\
\text { (6 months to } 5 \text { years old), } \\
\text { school-aged Children (ages } 6 \\
\text { to } 12 \text { ) and adolescents (ages } \\
13 \text { to 19) }\end{array}$ & $\begin{array}{l}14 \% \text { of Preschool children drank soft } \\
\text { drinks while } 17 \% \text { was school going } \\
\text { children and } 25 \% \text { were adolescents. }\end{array}$ & $\begin{array}{l}\text { Golloso Gubat MJ, et } \\
\text { al. [20] }\end{array}$ \\
\hline $\begin{array}{c}\text { A Study On Nutritional Status } \\
\text { And Dietary Quality According To } \\
\text { Carbonated Drink Consumption In } \\
\text { Male Adolescent [21]. }\end{array}$ & $\begin{array}{l}\text { Survey based } \\
\text { study }\end{array}$ & $\begin{array}{l}\text { Adolescents taken from } \\
\text { KNHANES 2007-2009 } \\
\text { SURVERY. Subjects were } \\
\text { split into two groups: LCDI } \\
\text { (low intake of carbonated } \\
\text { beverages (<1 time / } \\
\text { week), n = 362) and HCDI } \\
\text { (high intake of carbonated } \\
\text { beverages (about } 1 \text { time / } \\
\text { week), }\end{array}$ & $\begin{array}{l}\text { HCDI had lower consumption of plant } \\
\text { protein, } \\
\text { fruits and vegetables, vitamin C, } \\
\text { Potassium etc. The estimated } \\
\text { adequate requirement of protein and } \\
\text { vitamin c was also lower in HCDI. }\end{array}$ & Bae YJ, et al. [21] \\
\hline $\begin{array}{c}\text { Knowledge, Attitudes And } \\
\text { Practices Toward Energy Drinks } \\
\text { Among Adolescents In Saudi } \\
\text { Arabia [26]. }\end{array}$ & $\begin{array}{l}\text { Cross sectional } \\
\text { study }\end{array}$ & $\begin{array}{c}1061 \text { school children aged } \\
\text { 2-19years }\end{array}$ & $\begin{array}{l}\text { Males consume energy drinks at } 71.3 \\
\text { percent and females consume energy } \\
\text { drinks at } 35 \text { percent. } 58 \% \text { choose } \\
\text { it for taste while } 43 \% \text { for gender } \\
\text { difference. } 67 \% \text { considered energy } \\
\text { drinks to be soft drinks. }\end{array}$ & $\begin{array}{l}\text { Musaiger AO, et al. } \\
\qquad[26]\end{array}$ \\
\hline
\end{tabular}


Table 2: Energy Drinks Consumption / Soft Drinks Consumption.

\begin{tabular}{|c|c|c|c|c|}
\hline Title & Study design & Sample characteristics & Results & References \\
\hline $\begin{array}{l}\text { Associating Factors On Energy } \\
\text { Drinks Intake Of Some Middle } \\
\text { School Students In Incheon Area } \\
\text { [36]. }\end{array}$ & $\begin{array}{l}\text { Cross sectional } \\
\text { study }\end{array}$ & $\begin{array}{l}313 \text { middle school students } \\
\text { in inchon area from which } \\
133 \text { male students and } 180 \\
\text { female students }\end{array}$ & $\begin{array}{c}\text { Recognition of energy drinks monster } \\
\text { energy } 13.8 \% \text {, red bull } 24.3 \% \text {, wolf energy } \\
13.8 \% \text { this study show that there was } \\
\text { more difference in energy consumption, } \\
\text { consumption purpose, intake time and } \\
\text { location but the energy drink duration did } \\
\text { not vary }\end{array}$ & $\begin{array}{l}\text { Oh JW, et al. } \\
{[36]}\end{array}$ \\
\hline $\begin{array}{l}\text { Soft drink and sweet food } \\
\text { consumption and suicidal } \\
\text { behaviors among Chinese } \\
\text { adolescents [37]. }\end{array}$ & $\begin{array}{l}\text { Observational } \\
\text { study }\end{array}$ & $\begin{array}{l}100 \text { schools aged } 12 \text { to } 19 \\
\text { years was chosen in } 2005 \text { in } \\
\text { jiangsu province china. }\end{array}$ & $\begin{array}{l}\text { Soft drink intake in students was } 20.5 \text { percent } \\
\text { and suicidal ideation was } 18.6 \text { percent. } \\
\text { Suicide attempt incidence figure was } 6.2 \\
\text { percent for people who don't consume soft } \\
\text { beverages and } 12.8 \text { percent for those who } \\
\text { drink at least three times a day }\end{array}$ & $\begin{array}{l}\text { Pan X, et al. } \\
\text { [37] }\end{array}$ \\
\hline $\begin{array}{c}\text { Adolescent Energy Drink } \\
\text { Consumption: An Australian } \\
\text { Perspective [38]. }\end{array}$ & $\begin{array}{l}\text { Observational } \\
\text { study }\end{array}$ & $\begin{array}{l}399 \text { Australian teens aged } \\
12-18 \text { years }\end{array}$ & $\begin{array}{c}56 \text { percent lifetime intake of energy drinks. } \\
28 \text { per cent of the study ingested on a } \\
\text { monthly basis and } 36 \text { per cent of users } \\
\text { surpass the regular recommendation's intake } \\
\text { cap, we found that because of less education, } \\
\text { the majority of participants assume that } \\
\text { energy drinks is healthy for children, } \\
\text { teenagers and adults }\end{array}$ & $\begin{array}{l}\text { Costa BM, et al. } \\
\text { [38] }\end{array}$ \\
\hline $\begin{array}{l}\text { Energy Drink Consumption Status } \\
\text { And Associated Factors Among } \\
\text { Male And Female High School } \\
\text { Students In Dejon Area [39]. }\end{array}$ & $\begin{array}{l}\text { Cross sectional } \\
\text { study }\end{array}$ & $\begin{array}{l}664 \text { high school students } \\
\text { were picked at fifteen }\end{array}$ & $\begin{array}{l}73 \text { percent of students have been consuming } \\
\text { energy drinks. Male students drink more than } \\
\text { female students .the intake of energy drink } \\
\text { was nice taste of energy drink } 28 \text { percent, } \\
\text { remain alive } 54 \text { percent from the ingestion of } \\
\text { energy drink and } 17 \text { percent concentration } \\
\text { percentage }\end{array}$ & Ryu SH [39] \\
\hline $\begin{array}{l}\text { An Emerging Adolescent Health } \\
\text { Risk: Caffeinated Energy Drink } \\
\text { Consumption Patterns Among } \\
\text { High School Students [30]. }\end{array}$ & $\begin{array}{l}\text { Cross sectional } \\
\text { Study }\end{array}$ & $\begin{array}{l}\text { In } 2012,8,210 \text { students } \\
\text { from the } 7,9,10 \text { and } 12 \\
\text { classes were obtained from } \\
\text { schools in new found land, } \\
\text { canada. }\end{array}$ & $\begin{array}{c}\text { Value of energy drinks among high school } \\
\text { students was too high. In the end, the effect } \\
\text { was depression and sensation seeking people } \\
\text { who were linked to non-users for energy } \\
\text { drinks. }\end{array}$ & $\begin{array}{c}\text { Azagba S, et al. } \\
{[30]}\end{array}$ \\
\hline $\begin{array}{l}\text { Fast-food and full-service } \\
\text { restaurant consumption and daily } \\
\text { energy and nutrient intakes in US } \\
\text { adults [40] }\end{array}$ & $\begin{array}{l}\text { Observational } \\
\text { study }\end{array}$ & $\begin{array}{l}18,098 \text { national health } \\
\text { adults at the age of } 18 \text {, and } \\
\text { a 2003-2010 diet study had } \\
\text { been noted }\end{array}$ & $\begin{array}{l}\text { Avoid fast food due to the high number of } \\
\text { total fats, saturated fat and cholesterol when } \\
\text { full restaurant food was consumed from } \\
\text { home at the time }\end{array}$ & Jan An R [40] \\
\hline $\begin{array}{c}\text { Energy Drink And Nutritional } \\
\text { Supplement Beliefs Among Naval } \\
\text { Aviation Candidates [41] }\end{array}$ & $\begin{array}{l}\text { Survey based } \\
\text { study }\end{array}$ & $\begin{array}{l}\text { Anonymous } 44 \text { item survey } \\
\text { collected from naval } \\
\text { aviation candidates }\end{array}$ & $\begin{array}{c}\text { Response rate of } 100 \text { per cent among energy } \\
\text { drinks in this }\end{array}$ & $\begin{array}{l}\text { Sather TE, et al. } \\
\qquad[41]\end{array}$ \\
\hline $\begin{array}{c}\text { Consumption Of Carbonated Soft } \\
\text { Drinks Among Young Adolescents } \\
\text { Aged } 12 \text { To } 15 \text { Years In } 53 \text { Low- } \\
\text { And Middle-Income Countries } \\
\text { [43] }\end{array}$ & $\begin{array}{l}\text { Survey based } \\
\text { study }\end{array}$ & $\begin{array}{l}137449 \text { young adolescents } \\
\text { between the ages of } 12 \text { and } \\
15 \text { was chosen from schools } \\
\text { in different countries }\end{array}$ & $\begin{array}{c}95 \text { percent of teenagers drink carbonated } \\
\text { beverages } 1.39 \text { times a day and } 53 \text { percent } \\
\text { of teenagers eat carbonated drinks once } \\
\text { a day. In comparison, kiribati consumes } \\
0.52 \text { per cent of carbonated drinks and } \\
\text { suriname consumes } 2.39 \text { per cent. Soft drink } \\
\text { consumption is higher in middle income than } \\
\text { low income }\end{array}$ & $\begin{array}{l}\text { Yang L, et al. } \\
\qquad[43]\end{array}$ \\
\hline $\begin{array}{l}\text { Soft Drink Consumption in Sri } \\
\text { Lankan Adolescents [44] }\end{array}$ & $\begin{array}{l}\text { Cross Sectional } \\
\text { study }\end{array}$ & $\begin{array}{l}\text { Adolescents aged } 17 \text { years } \\
\text { attending sixty-five schools. }\end{array}$ & $\begin{array}{c}82 \% \text { of the students drank soft drinks once } \\
\text { a week while } 48 \% \text { drank soft drinks once a } \\
\text { week. }\end{array}$ & $\begin{array}{c}\text { Ratnayake N } \\
{[44]}\end{array}$ \\
\hline $\begin{array}{l}\text { A Knowledge, Attitude and } \\
\text { Practices Of Soft Drinks Among } \\
\text { Adolescent Students And Their } \\
\text { Dental Health [45] }\end{array}$ & $\begin{array}{l}\text { A questionnaire } \\
\text { Study }\end{array}$ & 100 Mba students & $\begin{array}{c}58 \% \text { of students consume carbonated } \\
\text { beverages twice a day, } 39 \% \text { of students } \\
\text { face problems after intake and } 48 \% \text { feel } \\
\text { discomfort after a couple of minutes of } \\
\text { getting drinks }\end{array}$ & $\begin{array}{c}\text { Gupta R, et al. } \\
{[45]}\end{array}$ \\
\hline $\begin{array}{c}\text { Consumption of Sweetened } \\
\text { Beverages Among Adolescents - } \\
13 \text { To } 18 \text { Years [46] }\end{array}$ & $\begin{array}{l}\text { Observational } \\
\text { study }\end{array}$ & $\begin{array}{l}300 \text { people were chosen } \\
150 \text { female and } 150 \text { males }\end{array}$ & $\begin{array}{c}\text { Flavored soda was consumed daily while } \\
\text { canned fruit juices were rarely consumed } \\
\text { while fresh fruit juices were consumed once a } \\
\text { day or once every three days. }\end{array}$ & Paralkar N [46] \\
\hline $\begin{array}{l}\text { Analysis of The Consumption Of } \\
\text { Caffeinated Energy Drinks Among } \\
\text { Polish Adolescents [47] }\end{array}$ & $\begin{array}{l}\text { Survey based } \\
\text { study }\end{array}$ & 300 participants & $\begin{array}{l}67 \text { per cent of students consume energy } \\
\text { drinks. Sports drink intake is more of an } \\
\text { energy drink than any other. }\end{array}$ & $\begin{array}{c}\text { Nowak D, et al. } \\
{[47]}\end{array}$ \\
\hline
\end{tabular}




\begin{tabular}{|c|c|c|c|c|}
\hline $\begin{array}{l}\text { Energy Drinks Consumption } \\
\text { Pattern, Perceived Benefits } \\
\text { and Associated Adverse Effects } \\
\text { Amongst Students Of University } \\
\text { Of Dammam, Saudi Arabia [48] }\end{array}$ & $\begin{array}{l}\text { Cross sectional } \\
\text { study }\end{array}$ & $\begin{array}{c}412 \text { students which } \\
\text { included } 282 \text { males and } \\
130 \text { females }\end{array}$ & $\begin{array}{l}\text { Users of energy drinks were } 54.60 \text { percent } \\
\text { males and } 26.15 \text { percent females. There were } \\
36.70 \% \text { males and } 14.28 \% \text { females who } \\
\text { should never have suffered consequences }\end{array}$ & $\begin{array}{l}\text { Alsunni AA } \\
{[48]}\end{array}$ \\
\hline $\begin{array}{c}\text { Energy Drink Consumption } \\
\text { Trends Among College Students } \\
{[50]}\end{array}$ & $\begin{array}{l}\text { Survey based } \\
\text { study }\end{array}$ & $\begin{array}{l}496 \text { people in which } 51 \% \\
\text { people consume energy } \\
\text { drink to enjoy \& } 51 \% \\
\text { people will take soft drinks } \\
\text { for sleeping }\end{array}$ & $\begin{array}{l}\text { The study's main purpose teaches us } \\
\text { regarding soft drinks }\end{array}$ & $\begin{array}{c}\text { Mutabazi MV, } \\
\text { [50] }\end{array}$ \\
\hline $\begin{array}{l}\text { Factors That Influence Consumer } \\
\text { Purchasing Behavior in The } \\
\text { Consumption Of Coca Cola Novida } \\
\text { Malt Soft Drinks In Nairobi, Kenya } \\
\text { Njorge, John [51] }\end{array}$ & $\begin{array}{l}\text { Survey based } \\
\text { study }\end{array}$ & 377 is sample size & $\begin{array}{l}\text { They may be analyzing its frequency and } \\
\text { percentages by analyzing data }\end{array}$ & Njoroge J, [51] \\
\hline $\begin{array}{c}\text { Factors Associated with } \\
\text { Inadequate Milk Consumption } \\
\text { Among Adolescents: National } \\
\text { School Health Survey - Pense } \\
2012 \text { [52] }\end{array}$ & $\begin{array}{l}\text { A cross-sectional } \\
\text { study }\end{array}$ & 108,828 sample size & $\begin{array}{l}58.9 \% \text { adolescents were sufficient of milk } \\
\text { intake }\end{array}$ & $\begin{array}{l}\text { Silva JB et al. } \\
\text { [52] }\end{array}$ \\
\hline
\end{tabular}

\section{Conclusion}

It was found that relationship among high intake of junk foods and unhealthy eating with adolescents and can be alleviate by nutrition education and creating awareness and setting different strategies and plans for creating more healthy practices among them.

\section{References}

1. Rodrigues PR, Luiz RR, Monteiro LS, Ferreira MG, Gonçalves Silva RM, et al. (2017) Adolescents' unhealthy eating habits are associated with meal skipping. Nutrition 42: 114-120.

2. Ganasegeran $\mathrm{K}, \mathrm{Al}$ Dubai SA, Qureshi AM, Al Abed AA, Rizal AM, et al. (2012) Social and psychological factors affecting eating habits among university students in a Malaysian medical school: A cross-sectional study. Nutr J 11(1): 48.

3. Neslişah R, Emine AY (2011) Energy and nutrient intake and food patterns among Turkish university students. Nutrition research and practice 5(2): 117-123.

4. Washi SA, Ageib MB (2010) Poor diet quality and food habits are related to impaired nutritional status in 13-to 18-year-old adolescents in Jeddah. Nutr Rese 30(8): 527-534.

5. Shah T, Purohit G, Nair SP, Patel B, Rawal Y, et al. (2014) Assessment of obesity, overweight and its association with the fast-food consumption in medical students. J of clin and diag rese: JCDR 8(5): CC05.

6. Anderson B, Lyon Callo S, Fussman C, Imes G, Rafferty AP (2011) Peer reviewed: Fast-food consumption and obesity among michigan adults. Preventing chronic disease 8(4): A71.

7. Al Otaibi HH, Basuny AM (2015) Fast food consumption associated with obesity/overweight risk among University female student in Saudi Arabia. Paki J of Nutr 14(8): 511.

8. Van Hook J, Altman CE (2012) Competitive food sales in schools and childhood obesity: A longitudinal study. Sociology of education 85(1): 23-39.

9. Larson N, Story M (2010) Are 'competitive foods' sold at school making our children fat? Health Affairs 29(3): 430-435.

10. Mozaffarian D, Hao T, Rimm EB, Willett WC, Hu FB (2011) Changes in diet and lifestyle and long-term weight gain in women and men. New Engl J of Medi 364(25): 2392-2404.
11. Keller A, Bucher Della Torre S (2015) Sugar-sweetened beverages and obesity among children and adolescents: A review of systematic literature reviews. Childhood Obesi 11(4): 338-346.

12. Fletcher EA, Mc Naughton SA, Crawford D, Cleland V, Della Gatta J, et al. (2018) Associations between sedentary behaviours and dietary intakes among adolescents. Publ heal nutr 21(6): 1115-1122.

13. Yang L, Bovet P, Liu Y, Zhao M, Ma C, et al. (2017) Consumption of carbonated soft drinks among young adolescents aged 12 to 15 years in 53 low-and middle-income countries. Amer J of publ heal 107(7): 10951100.

14. Wang H, Jeong H, Kim NH, Kang Y, Hwang K, et al. (2018) Association between beverage intake and obesity in children: The Korea National Health and Nutrition Examination Survey (KNHANES) 2013-2015. Nutrition research and practice 12(4): 307-314.

15. Beal T, Morris SS, Tumilowicz A (2019) Global Patterns of Adolescent Fruit, Vegetable, Carbonated Soft Drink, and Fast-Food Consumption: A Meta-Analysis of Global School-Based Student Health Surveys. Food and Nutrition Bulletin 40(4): 444-459.

16. Petticrew M, Knai C, Thomas J, Rehfuess EA, Noyes J, et al. (2019) Implications of a complexity perspective for systematic reviews and guideline development in health decision making. BMJ glob heal 4(Suppl 1).

17. Rafoss M (2017) The association between sugar sweetened or carbonated beverages and bone mineral density in adolescents taking part in the Fit Futures Study. UiT Norges arktiske universitet.

18. Vorland CJ, Stremke ER, Moorthi RN, Gallant KM (2017) Effects of excessive dietary phosphorus intake on bone health. Current osteoporosis reports 15(5): 473-482.

19. Al Raddadi R, Bahijri S, Borai A, AlRaddadi Z (2018) Prevalence of lifestyle practices that might affect bone health in relation to vitamin $\mathrm{D}$ status among female Saudi adolescents. Nutr 45: 108-113.

20. Golloso Gubat MJ, Magtibay EV, Gironella GM, Tajan MG, Constantino MA (2015) Beverage consumption of Filipino children and adolescents $\left(7^{\text {th }}\right.$ National Nutrition Survey): Nutritional concerns and potential policy implications. Phil J of Scie 144(1): 31-41.

21. Bae YJ, Yeon JY (2015) A Study on nutritional status and dietary quality according to carbonated drink consumption in male adolescents: Based on 2007 2009 Korean National Health and Nutrition Examination Survey. J of Nutr and Heal 48(6): 488-495. 
22. Zhou B, Huang Y, Li H, Sun W, Liu J (2016) Proton-pump inhibitors and risk of fractures: An update meta-analysis. Osteoporosis international 27(1): 339-347.

23. Bedi N, Dewan P, Gupta P (2014) Energy drinks: Potions of illusion. Indian pediatrics 51(7): 529-533.

24. Malik VS, Hu FB (2012) Sweeteners and risk of obesity and type 2 diabetes: The role of sugar-sweetened beverages. Current diabetes reports 12(2): 195-203.

25. Bleich SN, Vercammen KA, Koma JW, Li Z (2018) Trends in beverage consumption among children and adults, 2003 2014. Obesity 26(2): 432-441.

26. Musaiger AO, Zagzoog N (2014) Knowledge, attitudes, and practices toward energy drinks among adolescents in Saudi Arabia. Global journal of health science $6(2): 42-46$.

27. Seifert SM, Schaechter JL, Hershorin ER, Lipshultz SE (2011) Health effects of energy drinks on children, adolescents, and young adults. Pediatrics 127(3): 511-528.

28. Ebbeling CB, Feldman HA, Chomitz VR, Antonelli TA, Gortmaker SL, et al. (2012) A randomized trial of sugar-sweetened beverages and adolescent body weight. New Engl J of Medi 367(15): 1407-1416.

29. Rath M (2012) Energy drinks: What is all the hype? The dangers of energy drink consumption. J of the Amer Acad of Nurse Prac 24(2): 7076.

30. Azagba S, Langille D, Asbridge M (2014) An emerging adolescent health risk: Caffeinated energy drink consumption patterns among high school students. Prev Medi 62: 54-59.

31. Das S, Rajput SS (2013) Toxic Level of Soft Drinks and Sports Drink on Health Status. Inte J of Adva in Phar Biol and Chem 2(4).

32. Arria AM, Bugbee BA, Caldeira KM, Vincent KB (2014) Evidence and knowledge gaps for the association between energy drink use and high-risk behaviors among adolescents and young adults. Nutr revi 72(suppl_1): 87-97.

33. Alhumud M, Moore S, Morgan K (2020) Energy Drink Mechanisms of Harm in Young People and Adolescents: A Narrative Review. J of Food and Nutr Rese 8(1): 33-38.

34. Katzmarzyk P, Broyles S, Champagne C, Chaput JP, Fogelholm M, et al. (2016) Relationship between soft drink consumption and obesity in 9-11 years old children in a multi-national study. Nutr 8(12): 770.

35. Aziz F, Ali MM, Jabeen F (2017) Prevelance of Overweight and Obesity among Young Female Students in association with BMI. RADS J of Biol Rese \& Appl Scie 8(2): 01-04

36. Oh JW, Jang JS (2017) Associating factors on energy drinks intake of some middle school students in Incheon area. The Kore J of Food and Nutr 30(3): 618-626.

37. Pan X, Zhang C, Shi Z (2011) Soft drink and sweet food consumption and suicidal behaviors among Chinese adolescents. Acta 100(11): e215-222.

38. Costa BM, Hayley A, Miller P (2016) Adolescent energy drink consumption: An Australian perspective. Appe 105: 638-642.

39. Ryu SH (2016) Energy drink consumption status and associated factors among male and female high school students in Deajon area. The Kore J of Food and Nutr 29(6): 899-910.

40. An R (2016) Fast-food and full-service restaurant consumption and daily energy and nutrient intakes in US adults. Euro J of Clin Nutr 70(1): 97-103.

41. Sather TE, Woolsey CL, Delorey DR, Williams RD (2018) Energy Drink and Nutritional Supplement Beliefs Among Naval Aviation Candidates. Aerospace medicine and human performance 89(8): 731-736.

42. Sawyer SM, Azzopardi PS, Wickremarathne D, Patton GC (2018) The age of adolescence. The Lanc Chil \& Adol Heal 2(3): 223-228.
43. Yang L, Bovet P, Liu Y, Zhao M, Ma C, et al. (2017) Consumption of carbonated soft drinks among young adolescents aged 12 to 15 years in 53 low-and middle-income countries. Amer J of publ heal 107(7): 10951100.

44. Ratnayake N, Ekanayake L (2012) Soft drink consumption in Sri Lankan adolescents. Publ heal nutria 15(8): 1333-1337.

45. Gupta R, Solanki A, Sharma S, Gumber P, Sharma A, et al. (2015) A knowledge, attitude, and practices of soft drinks among adolescent students and their dental health: A Questionnaire study. Inte J of Dent Heal Conc 1(1): 1-5.

46. Paralkar N, Shekar MA (2016) Consumption of Sweetened Beverages Among Adolescents-13 To 18 Years.

47. Nowak D, Jasionowski A (2015) Analysis of the consumption of caffeinated energy drinks among Polish adolescents. International J of envi rese and publ heal 12(7): 7910-7921.

48. Alsunni AA, Badar A (2011) Energy drinks consumption pattern, perceived benefits and associated adverse effects amongst students of University of Dammam, Saudi Arabia. J of Ayub Medi Coll Abbo 23(3): 3-9.

49. Born KA, Dooley EE, Cheshire PA, Mc Gill LE, Cosgrove JM, et al. (2019) Chocolate Milk versus carbohydrate supplements in adolescent athletes: A field-based study. J of the Inte Soci of Spor Nutr 16(1): 6.

50. Mutabazi MV (2019) A Survey of Energy Drink Consumption Patterns among College Students: An Article Review. EC Emer Medi and Crit Care 3: 224-233.

51. Njoroge J (2017) Factors That Influence Consumer Purchasing Behaviour in the Consumption of Coca Cola Novida Malt Soft Drinks in Nairobi, Kenya (Doctoral dissertation, United States International University-Africa).

52. Silva JB, Elias BC, Mais LA, Warkentin S, Konstantyner T, et al. (2020) Factors Associated with Inadequate Milk Consumption Among Adolescents: National School Health Survey-Pense 2012. Revista Paulista de Pediatria 38.

53. Taher AK, Evans N, Evans CE (2019) The cross-sectional relationships between consumption of takeaway food, eating meals outside the home and diet quality in British adolescents. Publ heal nutr 22(1): 63-73.

54. Krishna GR, Somavarapu S (2018) Preference for Restaurant Foods Over Home Made. Research \& Reviews: J of Food Scie and Tech 6(3): 348.

55. Mandoura N, Al Raddadi R, Abdulrashid O, Shah HB, Kassar SM, et al (2017) Factors associated with consuming junk food among Saudi adults in Jeddah city. Cureus 9(12): e2008.

56. Sanlier N, Sezgin AC, Sahin G, Yassibas E (2018) A study about the young consumers' consumption behaviors of street foods. Ciencia \& saude coletiva 23: 1647-1656.

57. Agarwal VV, Makhija PA (2019) A study on junk food consumption behavior among college students. Inte Rese J of Engi and Tech 6(3): 4185-4192.

58. Banik R, Naher S, Pervez S, Hossain MM (2020) Fast food consumption and obesity among urban college going adolescents in Bangladesh: A cross-sectional study. Obes Medi 17: 100161.

59. Lopez Quintero C, Freeman P, Neumark Y (2009) Hand washing among school children in Bogota, Colombia. Amer J of Publ Heal 99(1): 94-101.

60. Peltzer K, Pengpid S (2014) Oral health behaviour and social and health factors in university students from 26 low- middle- and high-income countries. Inte J of envi Rese and publ heal 11(12): 12247-12260.

61. PekerI, Alkurt MT (2009) Oral health attitudes and behavior among a group of Turkish dental students. Europ J of dent 3(1): 24-31.

62. Sultana M, Mahumud RA, Sarker AR, Hossain SM (2016) Hand hygiene knowledge and practice among university students: evidence from 
Private Universities of Bangladesh. Risk management and healthcare policy 9: 13.

63. Sihra J, Meena G, Meena N, Naroliya D, Saini L, Kaur M, Gaur K (2018) Assessment of Knowledge and Practices regarding personal hygiene

\section{ISSN: 2574-1241}

DOI: $10.26717 /$ BJSTR.2021.33.005389

Sidra Khalid. Biomed J Sci \& Tech Res

(c) (P) This work is licensed under Creative

Submission Link: https://biomedres.us/submit-manuscript.php among students at Government schools of Jaipur city: A cross-sectional survey. IMJH 4(4): 125-130.

$\begin{array}{ll}\text { BIOMEDICAL } & \text { Assets of Publishing with us } \\ \text { RESEARCHES } & \text { - Global archiving of articles } \\ \text { - Immediate, unrestricted online access }\end{array}$

